\title{
Eggs of tegu lizard, Salvator merianae (Duméril \& Bilbron, 1839) (Squamata; Teiidae) damaged by fungal infections
}

\author{
A. M. Carvalho ${ }^{a *(D)}$ L. K. H. Souza ${ }^{b}$, F. S. Ataides ${ }^{b}$ and A. K. Péres Junior \\ ${ }^{a}$ Faculdade de Agronomia e Medicina Veterinária - FAV, Universidade de Brasília - Unb, CEP 70910-970, \\ Brasília, DF, Brasil
}
bDepartamento de Microbiologia, Instituto de Patologia Tropical e Saúde Pública, Universidade Federal de Goiás - UFG, CEP 74605-050, Goiânia, GO, Brasil
'Departamento de Zoologia, Universidade de Brasília - Unb, CEP 70910-900, Brasília, DF, Brasil
*email: andreavet.carvalho@yahoo.com.br

Received: March 24, 2018 - Accepted: August 14, 2018 - Distributed: February 28, 2020

(With 1 figure)

\begin{abstract}
The tegu (Salvator merianae) is the largest lizard found in Brazil and has a wide distribution, occurring in several biomes. The presence of fungi on reptilian eggs initially occurs on infertile eggs, which leads to a subsequent infection in fertile eggs, causing damage and death of embryos. The objective of this study was to identify the fungi that caused lesions in the eggs of tegu in captivity. Swabs were collected on infected and healthy eggshells, in an embryo that died and the substrate of the incubation box. Samples were submitted to saboraund dextrose agar. A total of $93.3 \%$ of positive samples were obtained for the fungi Fusarium (11/14), Trichoderma (1/15), Penicilium (1/15), Mucor (1/15), and yeasts of the genus Trichosporon. Therefore, Fusarium was the main agent that caused the lesion and death of embryos in the eggs of the tegu lizard. Sanitary control methods may be taken to avoid fungal infections in the eggs.
\end{abstract}

Keywords: artificial egg incubation, Fusarium infection, reptiles.

\section{Ovos de lagarto tegu, Salvator merianae (Duméril e Bilbron, 1839) (Squamata; Teiidae) danificados por infecções fúngicas.}

\begin{abstract}
Resumo
O teiú (Salvator merianae) é o maior lagarto encontrado no Brasil e possui ampla distribuição, sendo encontrado em vários biomas. A presença de fungos em ovos de répteis ocorre inicialmente em ovos inférteis, o que leva à uma infecção posterior em ovos férteis, gerando danos e morte dos embriões. O objetivo deste estudo foi o de identificar os fungos geradores de lesões em ovos de teiú em cativeiro. Foram coletados suabes na casca de ovos infectados e sadios, além de um embrião que veio a óbito, e do substrato presente na caixa de incubação. As amostras foram submetidas ao cultivo em ágar Saboraund dextrose. Um total de 93,3\% de amostras foram positivas para os fungos Fusarium (11/15), Trichoderma (1/15), Penicillium (1/15), Mucor (1/15) e leveduras do gênero Trichosporon (3/15). Logo, Fusarium foi o principal agente causador das lesões e morte de embriões nos ovos do lagarto teiú. Métodos de controle sanitário podem ser adotados para evitar infecção fúngicas nos ovos.
\end{abstract}

Palavras-chave: incubação artificial de ovos, infecção por Fusarium, répteis

\section{Introduction}

The tegu Salvator merianae (Duméril \& Bilbron, 1839) (Squamata; Teiidae), is the largest lizard of the Teiidae family, and presents an annual and oviparous reproduction. Females can lay up to 40 eggs (Donadio and Gallardo, 1984), and differ from most of the lizards species, by presenting parental care towards the clutch (incubation and protection) during fetal development, which lasts from 60 to 70 days (Chani et al., 1993). Infertile or nonviable eggs can compromise reproduction by promoting fungi colonization of fertile eggs (Moreira and Barata, 2005). Phillott and Parmenter (2001) described that fungi are often found in eggshells from hatched sea turtles in Australia. Moreira and Barata (2005) reported in artificial incubation the presence of the fungus Fusarium sp. and Gliocladium sp., initially colonizing infertile eggs, and later spreading to fertile eggs, contributing to embryos death. Assuming that fungi are components of microbiota of reptiles hosts, and that eggs have a predisposition to infections from opportunistic environmental fungi, this study aimed to isolate and identify fungal agents that affects tegu lizard eggs, during artificial incubation in a commercial captivity. 


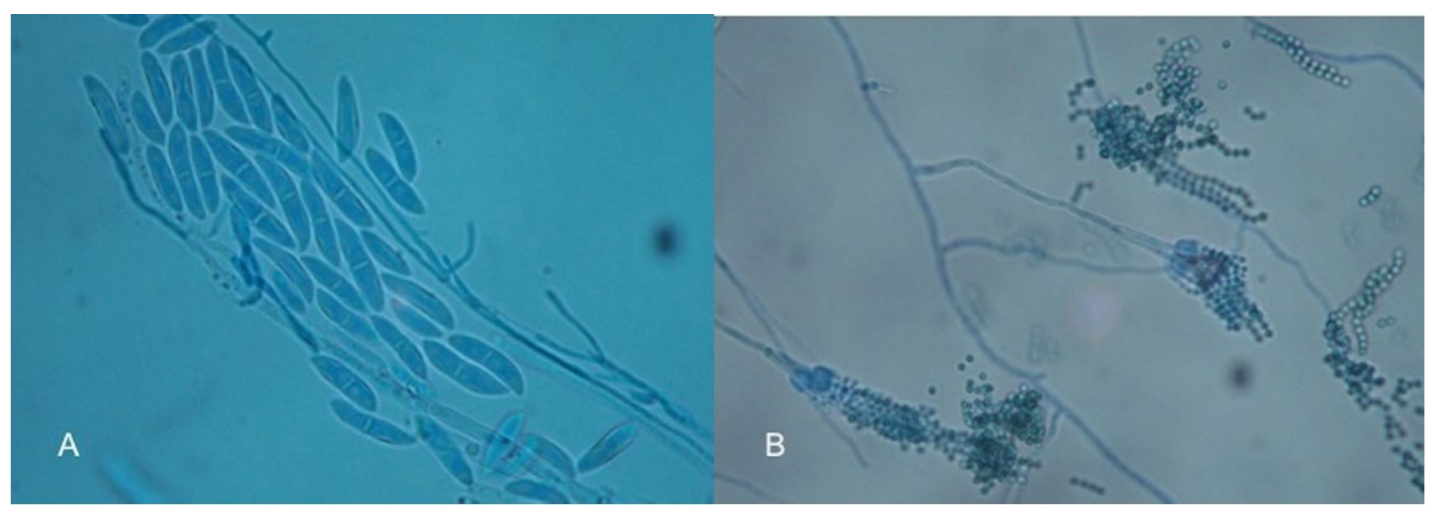

Figure 1. A) Conidia of Fusarium sp.; B) Penicillium sp., both cultivated on saboraund dextrose agar.

Table 1. Fungal growth on different samples collected and analyzed (*UC - Unidentified Colonies).

\begin{tabular}{|c|c|c|c|c|c|c|c|}
\hline Samples & Total & Fusarium sp. & Trichosporon sp. & Mucor sp. & Penicilium sp. & Trichoderma sp. & ${ }^{*} \mathbf{U C}$ \\
\hline Infected eggshells & 11 & 10 & 1 & 1 & - & - & 1 \\
\hline Healthy eggshells & 2 & - & - & - & - & 1 & - \\
\hline$\left(\right.$ Vermiculite $^{\circledR}$ ) & 1 & - & 1 & - & 1 & - & - \\
\hline Dead embryo & 1 & 1 & - & - & - & - & - \\
\hline
\end{tabular}

\section{Material and Methods}

Samples were collected in a commercial breeding facility of Salvator merianae, located in Distrito Federal, Center-western Brazilian region, and registered and licensed by the IBAMA - Intituto Brasileiro do Meio Ambiente e dos Recursos Naturais Renováveis. From 15 samples collected, 11 eggshells presented lesions, 2 were from healthy eggshells, 1 from a dead embryo, and another from substrate used for incubation (Vermiculite ${ }^{\circledR}$ ) with fungal growth. We used sterile swabs that were placed in sterile capped tube, properly identified and mantained at room temperature. Samples were processed at the Laboratório de Micologia Universidade Federal de Goiás. Samples were inoculated on Sabouraud dextrose agar with chloramphenicol, and incubated at room temperature for 15 days, with daily observation of colony growth. Identification of filamentous fungi was made by macroscopic characteristics of the colony, and by microscopic analysis of asexual reproduction structures (Dugan, 2006). When it was not possible to identify fungi through colony replating, microculture technique was used (Harris, 1986).

\section{Results}

From the 15 samples analyzed, 14 presented fungal growth belonging to five different genera. Fusarium sp. was observed in 10 samples of injured eggshells and in the dead embryo sample (Figure 1A). In an injured eggshell, growth of Fusarium sp. together with Trichosporon sp. was observed, and in another, Fusarium sp. and Mucor sp. were found. On substrate sample, Trichosporon sp. and Penicillium sp. were isolated (Figure 1B). The healthy eggshell sample presented Trichoderma sp. growth. The other healthy eggshell sample was negative for fungal growth.
One sample of infected eggshell presented unidentified colonies (Table 1).

\section{Discussion}

According to Phillott and Parmenter (2001), eggs of sea turtles are affected by microorganisms found in soil, such as Fusarium solani. Those fungi initially affect unfertile eggs or with dead embryos, and gradually spread to adjacent and fertile eggs, reducing clutch hatching rate. Further, Paré et al. (2003) described fungi such as Aspergillus spp., Penicillium spp. and Paecilomyces lilacinus as components of the skin microflora of healthy reptiles. Another study evaluated the cloacal microbiota in reptiles, in order to isolate zoonotic fungi in lizards, snakes and turtles, sold in pet stores (Nardoni et al., 2008). The authors observed the presence of fourteen filamentous fungi, including eight species of Aspergillus and six genera of yeast, such as Candida, Cryptococcus and Pichia. Therefore, although infection of eggs occurs mainly through contact with fungi presented in the environment, it is possible that fungi found in the microbiota of reptiles may infect the eggs at oviposition time. In our study, the high prevalence of Fusarium sp. in the samples examined, indicates that this fungus may be the main cause of tegus egg's mortality in artificial incubation. Fusarium species are known sources of focal lesions on humans and animals, with high morbidity and mortality (Summerbell, 2003). Injuries resulting from the action of Fusarium solani, similar to those found in eggs of captive tegu, were observed by Sarmiento-Ramirez et al. (2010) in 25 samples of turtle eggs (Careta careta). Such as in the eggs of tegu lizards of this study, Fusarium solani was isolated in embryos of turtle eggs, corroborating the idea that this fungus may cause embryonic death of infected eggs (Sarmiento-Ramirez et al., 2010). 
Since fungi may be causing damages and embryonic death in the eggs of tegu lizard, it is fundamental to control and prevent the clutches from becoming infected. It is recommended the disinfection of the incubation room, substrate, and eggs as a sanitary control measure in artificial incubation of captive tegu eggs, in order to decrease fungal infections, especially by Fusarium spp. Further, the removal of nonviable eggs that can trigger proliferation of fungal hyphae is key to increase the survival rate of embryos, and the hatching rate of clutches.

\section{Acknowledgements}

We would like to thank the "Fazenda Amigos do Cerrado" farm for facilitating the collection of biological samples and to the Laboratório de Micologia Universidade Federal de Goiás for enabling the sample processing and analysis.

\section{References}

CHANI, J.M., CRUZ, F., PEROTTI, G., AGUIRRE, M.Y. and RUFFINO, S., 1993. Rol de la hembra Salvator teguixin (Teiidae) durante la nidificación. Acta Zoológica, vol. 42, pp. 295-299.

DONADIO, O.E. and GALLARDO, J.M., 1984. Biología y conservación de las especies del género Salvator (Squamata, Sauria, Teiidae) en la República Argentina. Revista del Museo Argentino de Ciencias Naturales Bernardino Rivadavia. Zoologia, vol. 13, pp. 117-127.

DUGAN, F.M., 2006. The Identification of Fungi: an Illustrated Introduction with key, Glossary and Guide to Literature. St. Paul. Minnesota: The American Phytopathological Society.
HARRIS, J.L., 1986. Modified method for fungal slide culture. Journal of Clinical Microbiology, vol. 24, no. 3, pp. 460-461. PMid:3760139.

MOREIRA, P.L. and BARATA, M., 2005. Egg mortality and early embryo hatching caused by fungal infection of Iberian rock lizard (Lacerta monticola) clutches. The Herpetological Journal, vol. 15 , pp. 265-272.

NARDONI, S., PAPINI, R., MARCUCCI, G.M. and MANCIANTI, F., 2008. Survey on the fungal flora of the cloaca of healthy pet reptiles. Revue de Medecine Veterinaire, vol. 159, pp. 159-165.

PARÉ, J.A., SIGLER, L., RYPIEN, K.L. and GIBAS, C.F.C., 2003. Cutaneous mycobiota of captive Squamata reptiles with notes on the scarcity of Chrysosporium anamorph of Nannizziopsis vriesii. Journal of Herpetological Medicine and Surgery, vol. 13, no. 4, pp. 10-15. http://dx.doi.org/10.5818/1529-9651.13.4.10.

PHILLOTT, A.D. and PARMENTER, C.J., 2001. The distribution of failed eggs and the appearance of fungi in artificial nests of green (Chelonia mydas) and loggerhead (Caretta caretta) sea turtles. Australian Journal of Zoology, vol. 49, no. 6, pp. 713-718. http://dx.doi.org/10.1071/ZO00051.

SARMIENTO-RAMÍREZ, J.M., ABELLA, E., MARTIN, M.P., TELLERIA, M.T., LOPEZ-JURADO, L.F., MARCO, A. and DIEGUEZ-URIBEONDO, J., 2010. Fusarium solani is responsible for mass mortalities in nests of loggerhead sea turtle, Caretta caretta, in Boavista, Cape Verde. Federation of European Microbiological Societies, vol. 312, no. 2, pp. 192-200. http:// dx.doi.org/10.1111/j.1574-6968.2010.02116.x. PMid:20875054.

SUMMERBELL, R.C., 2003. Aspergillus, Fusarium, Sporothrix, Piedraia, and their relatives. In: D.J. Howard, ed. Pathogenic fungi in humans and animals. New York: Marcel Dekker Inc., pp. 237-307. 